\section{4 腰椎回旋時の椎間関節の機構運動}

1野猿峠脳神経外科病院

2ラッシュ医科大学整形外科

$$
\begin{aligned}
& \text { ○水野 正喜 }{ }^{1} \text { 岩本 邦憲 }{ }^{1} \text { 堀田 二郎 }{ }^{1} \\
& \text { 竹下 裕 }{ }^{1} \text { 安永 剭 }{ }^{1} \text { 井上 望 }{ }^{2}
\end{aligned}
$$

目的：腰椎変性疾患の病因には椎間関節の変性と可動性変 化が大きく関与しているが，正常椎間関節の動態に関しての 詳細な報告は少ない。我々は CT 画像から腰椎椎間関節の三 次元モデルを作製し，腰椎回旋時の椎間関節の機構運動につ いて計測, 評価した. 方法：健常な成人 34 例（男性 17 例, 女性 17 例：平均 36.6 歳）を対象とした. L1/2 から L5/S1 までの左右計 10 椎間関節について評価した。CT は骨条件, $1 \mathrm{~mm}$ 間隔， $512 \times 512$ マトリックス，仰臥位及び右方 50 度 回旋位で撮影した。この画像を基に，三次元椎間関節モデル を作製し，関節重心の移動べクトルを測定し機構運動を解析 した。結果：右方 50 度回旋により，左側上位関節面は左外 側から前方方向（下位関節面に近づく方向）に移動し，右側 上位関節面は左後外側方向（下位関節面から離れる方向）に 移動することが明らかとなった。関節面の移動方向とその距 離は各椎間で異なっていた，結果について図表を用い説明す る。

\section{2. 一般演題 II}

\section{5 重症頭部外傷術後に硬膜内脊髄くも膜囊腫を認めた 一例}

袋井市民病院脳神経外科

\section{○上眞宏 打田淳 市橋 鋭一}

外傷性くも膜下出血を伴う急性硬膜外血腫に対し, 開頭血 腫除去術後，硬膜内脊髄くも膜囊腫を認めた一例を経験した ので文献的考察を含め報告する．

症例：32 歳, 男性. 転倒による頭部打撲にて, 近医で頭 部精査したところ，急性硬膜外血腫，外傷性くも膜下出血な ど重傷頭部外傷を認め当院救急搬送となった。来院時頭部 CT 上急性硬膜外血腫の拡大，意識障害を認め，同日緊急開頭血 腫除去術施行となった。術翌日に左上腹部痛, 背部痛出現し, 腹部精査施行するも明らかな異常認められず。左上腹部痛は 約 3 日で改善するも，背部痛は持続していた，徐々に腰痛出 現し, 歩行開始後左下肢痛の訴えも認めた。術後 9 日目の腰 椎 MRI にて腰部硬膜内に囊胞を認め，それにより馬尾神経が 腹側へ圧迫されているのを認めた．脊髄造影を考慮するも徐々 に症状改善し, 術後 22 日目の腰椎 MRIにて, 硬膜内囊胞の 消失，馬尾神経の正常を認めた。腰痛，背部痛は軽度残存す るも，独歩可能にて退院となった.

\section{Spondylo-SEXTANT (SEXTANT2) の使用経験}

1 綾部ルネス病院脳神経外科

2 藤田保健衛生大学医学部脳神経外科

○深谷 賢司 ${ }^{1}$ 長谷川光広 $^{2}$

目的：腰椎すべり症に対し低侵襲に矯正固定が可能な Spondylo-SEXTANT（SEXTANT2）を使用した症例を報告する。 症例：67 歳, 男性. 間欠性跛行 $50 \mathrm{~m}$ 右下肢しびれ, 右下 腿痛にて当科受診した. L4/5に単純写にて変性すべり L4/5, 及び MRIにて著明な脊柱管狭窄を認めた，脊髄造影では L4/ 5 完全ブロックであった. 平成 20 年 1 月 16 日 L4/5 左進入両 側開空除圧術 TLIF を行った。 Cage 及び椎間腔には局所骨 を用いて自家骨移植した。経皮的にスクリュー挿入後 Spondylo-SEXTANT（SEXTANT2）を用い reduction した。術後レ ントゲン，CTにて alignment は良好であった. JOA スコア は 9 点から 22 点まで改善した。考察：経皮的椎弓根スク リューを用いてすべりの矯正が行うことができる SpondyloSEXTANT（SEXTANT2）は低侵襲手術に貢献すると期待さ れる。

\section{7 时部における拘扼性尺骨神経障害の解剖学的病態と 手術方法の選択}

親和会西島病院脳神経外科脳 · 脊䯣 · 心臓疾患センター ○工藤 陽平 安永 剛 山下 和彦 知秃 史郎 棚澤 利彦 木根一典 小野 博久 西島 洋司 橘 滋國

上肢における拘扼性末梢神経障害は広く知られているが, 时部管症候群の症例は比較的少ない，今日までに肘部管症候 群に対する多彩な手術方法が報告されており，これらを二つ に大別すると，絞扼部を開放し除压のみを行う神経剝離術と， さらに尺骨神経を内側上顆の前方へ移動させる神経移行術と なる。

今回，肘部における拘扼性尺骨神経障害の手術症例 51 例 について, 解剖学的病態と我々の手術方法の関係について検 討したので報告する。

肘部には，尺骨神経が拘扼を受けやすい 5 つの部位が存在 する.すなわち末梢側より(1)尺側手根屈筋の二頭の間 (Osborne のバンド), (2)肘部管（皮下結合織), (3)上腕骨内側上顆, (4) 筋間中隔, (5)Struthers のアーケードである. (1)(2)(5)での拘扼 は神経剝離術のみで良好な成績を得られる。(3)(4)の゙拘扼は 神経移行を行う必要性がある。また，術中所見において，尺 骨神経溝が浅く, 肘関節の屈曲により尺骨神経が上腕骨内側 上顆を乗り越え, 前方偏移を起こす症例では内側上顆切除術 （king 法）を加えたうえで神経移行術を施行することにより， 除圧を完全なものとすることが可能である。

術前に, Tinel 様徵候の部位, 神経伝導速度（インチング 法）で障害部位と病態をある程度想定することができるが, 術中所見が最も重要である。手術を行う際には，こうした部 